\title{
Archaeologia
}

http://journals.cambridge.org/ACH

Additional services for Archaeologia:

Email alerts: Click here

Subscriptions: $\underline{\text { Click here }}$

Commercial reprints: $\underline{\text { Click here }}$

Terms of use : Click here

\section{XII._On an Examination of the Tombs of Richard II. and Henry III. in Westminster Abbey}

Arthur Penrhyn Stanley

Archaeologia / Volume 45 / Issue 02 / January 1880, pp 309 - 327

DOI: 10.1017/S0261340900007049, Published online: 25 January 2012

Link to this article: http://journals.cambridge.org/abstract S0261340900007049

How to cite this article:

Arthur Penrhyn Stanley (1880). XII._-On an Examination of the Tombs of Richard II. and Henry III. in Westminster Abbey. Archaeologia, 45, pp 309-327 doi:10.1017/S0261340900007049

Request Permissions : $\underline{\text { Click here }}$ 
XII.-On an Examination of the Tombs of Richard II. and Henry III. in Westminster Abbey. By the Very Rev. Arthor Penrhyn Stanlex, D.D., F.S.A., Dean of Westminster.

Read June 26th, 1873.

TOMB OF RICHARD II.

The tomb of Richard II. has a triple interest: for Westminster Abbey; for English History generally; and for the Society of Antiquaries.

(1.) For the Abbey, Richard II. must remain, in spite of all his faults, one of its most familiar and consecrated personages. His coronation is described in the only volume handed down from mediæval times to the custody of the successive Deans of Westminster : namely, the Liber Regalis of Abbot Littlington, of which a reprint has lately been made for the Roxburghe Society by the munificence of Lord Beauchamp. The event was further marked by the first appearance of two features in the coronations, both especially connected with Westminster, the Champion, and the Knights of the Bath.

He was one of the three English Sovereigns married in the Abbey, the two others being Henry III. and Henry VII. His affection for it is proved by the colossal badge of the White Hart in the Triforium, and by the portrait which long tradition has ascribed to him, and which, after its marvellous restoration by $\mathrm{Mr}$. Richmond, has now returned as nearly as possible to its original place in the choir.

So anxiously too did he desire to be buried by the side of the Confessor, that, overleaping the precedent set by his father, the Black Prince, he cleared for himself and his Queen a place in St. Edward's Chapel by transporting the coffins and tomb of his two relations, the children of Humphrey de Bohun, to the chapel of St. John the Baptist.

He also, unconsciously perhaps, but not the less effectively, was the originator of the series of illustrious interments which began with his two favourites, John of Waltham, the first of the statesmen, and Robert Waldeby, the first of the men of letters, who were laid in the church, thereafter to receive the long line of graves of distinguished men in Church and State.

In the case of none of the Plantagenet tombs have we a more complete account of its building and of its ornaments; in none did the Sovereign himself take a keener interest during his lifetime. From none was any king kept away by such strange vicissitudes: carried away by his successor to King's Langley, 
as if to avoid the occasion of pilgrimages or demonstrations by his numerous adherents; then brought back years afterwards by the youth whom he had himself knighted; or perhaps, as the Scottish chronicler would have us believe, laid in the church of the Preaching Friars at Stirling on the north side of the altar.

(2.) Again, for the history of England his tomb marks the close of the first Plantagenet dynasty. The Lancastrian monuments which follow, whether in Westminster or elsewhere, are of a different type; and from this watershed of history the stream of events henceforth flows in a new direction.

In this tomb at Westminster the bones of Richard II. were laid, under circumstances so peculiar that no other like interment has occurred amongst our kings. No other royal death or burial is enveloped in so fearful a mystery as that occasioned by the threefold account of his death. The doubt was entertained in his own time whether the body brought from Pontefract, through London to King's Langley, was not that of his chaplain Maudelyn; and again, whether he was not long afterwards living a state prisoner in Scotland; and then there arose the pertinacious belief of his followers that he was still living like a Prince Henry of Portugal, or a King Arthur of Brittany, in the fortresses of the usurping successor."

The tragedy of his life is centered in his grave, and has been felt alike by poets and historians. The contrast between his portrait and his tomb close by is the same which so deeply impressed the contemporary chronicler of the fourteenth century, and is the same also which no less deeply impressed the poet of the eighteenth century.

"I saw," says Froissart, "two strange things in my time, though widely different, one was the rejoicings at Bordeaux on Richard's birth, the other was the funeral, when some pitied him, but others did not, saying that he had for long since deserved death." And so Gray in his great historical ode :-

Fair laughs the morn and soft the zephyr blows

While proudly riding o'er the aztre realm

In gallant trim, the gilded vessel goes;

Youth at the prow and pleasure at the helm,

Regardless of the sweeping whirlwind's sway,

That, hushed in grim repose, expects his living prey.

a Those who desire to examine the existing evidence and opinions upon this obscure question will do well to consult the following works:-Chronicque de la Traïson et Mort de Richart Deux Roy dengleterre, by B. Williams. English Historical Society, 1846. P. Fraser Tytler's History of Scotland. English Chronicle, Camden Society. Froissart's Chronicles, chap. 118-119, 121. Fox's History of Pontefract, p. 135-140. Devon's Pell Records, pp. 275-6. " Paid for carriage of the king's body from Pontefract to London, 66l. 13s. 4d." Archæologia, vol. vi. p. 314; vol. xx. pp. 220 and 428; vol. xxv. pp. 394-397; vol. xxviii. pp. 75,85 , and 95 . 
And is it not almost as with the feeling of his love for Westminster Abbey, and of the ghastly or ghostly interest that was to linger over his own tomb, that Richard II is described by Shakespeare:

For Heaven's sake, let us sit upon the ground, And tell sad stories of the death of kings.

Richard II. Act iii. Sc. 2.

(3.) This brings me to say, thirdly, that no assembly could be more interested in these questions than the Society of Antiquaries. The exhaustive discussion of the stories of Richard's deposition and death, by the Rev. John Webb and others, in the Archæologia, vol. xx. xxiii. xxv. xxviii. shows the keenness with which this Society entered into the matter; and it was Mr. King who, in the same work, vol. vi. (p. 315), gave the most formal account of that very irregular investigation which the antiquaries of the last century made by thrusting their hands through the vacant holes in the side of the tomb and pulling about the royal bones. The Dean of that day, Dean Thomas, very properly closed the holes, and from that time there has been no further exploration possible. But when by the courteous attention of the present First Commissioner of Works, Mr. Ayrton, to the repeated suggestions that he should follow in the course so well inaugurated by his predecessor, Mr. Layard, with regard to the royal monuments of the Tudor dynasty, the process of cleaning the Plantagenet tombs was undertaken, the opportunity was once more offered, and the grateful thanks of the Dean as well as of the public are due as heretofore to the Society of Antiquaries for the ready assistance which its distinguished members were able to render even at the dead season of the year when these investigations were conducted. In matters of such delicacy it is a rare advantage to be able to refer to a recognised oracle which could say, with the tact acquired by long experience and varied knowledge, where it was necessary to advance, where to withhold further research.

There is, in Mr. Nichols's very interesting account of the tomb of Richard II., in the Archæologia (xxix. p. 57) a very true, perhaps one might say a very severe, account of the state of the effigies. "For many generations," he says, " the gilding and pounce-work have been obscured by a thick varnish of indurated dust, until at last they were entirely forgotten, except for the tradition of the successive authors who have described the Abbey and its monuments." He takes the Government and the Dean and Chapter to task for this neglect. It was 
to wipe away this reproach that, in pursuance of the successful results of cleaning the tomb of Margaret, Countess of Richmond, and of cleansing and partly repairing that of King Henry VII., similar operations were set on foot in relation to Richard II.'s tomb.

From the appearance of the effigies and the great discoloration of the metal bed, as well as of the marble covering slabs, it was at first thought that the tomb had been entered in recent times, but it soon became evident that, although the effigies and their adjuncts had all been displaced, first through the dislocation gradually caused by the corrosion of the iron cramps in the sub-structure, secondly by the violence which had been used when the missing portions of the metal work had been abstracted, and thirdly by the circumstance that casts of all the metal work have been of late years taken for various exhibitions, \&c., yet the marble slabs forming the covering had certainly not been removed since the time when Henry $V$. finally placed the remains of his predecessor within the tomb.

An examination of the masonry also showed that the structure had been originally made as far as possible air-tight when the Queen was buried, for all the joints of the marble work were filled in with a resinous cement, technically called "grain," made of resin, wax, and stone dust; and this, having been thrust whilst hot into the open joints after the parts were fixed, had rendered all the junctions impervious. This precaution cannot have been repeated when the tomb was opened and again closed after the deposition of the King's body, as the evident use of mortar in the pointing would preclude the more careful treatment which had been adopted at the first interment.

This is of importance, as an additional proof that the tomb of Anne of Bohemia was already completed in the reign of Richard II., a fact indeed which was sufficiently clear from Richard's Will (see Nichols's Royal Wills, p. 192 et. seq.), and from the indentures for the work, printed by Neale (vol. ii. pp. 111-113), from Rymer's Fodera (vol. vii. p. 797). But as Dart " (vol. ii. p. 45) and others had maintained the opinion that it was built after the interment of Richard II. in the reign of Henry V., it is satisfactory to find that the argument from the structure is in entire accordance with the argument from the documents.

The metal work, which is of considerable weight, was first lifted up by means of pulleys and ropes into the Triforium, in order to permit the operations of cleansing, \&c., to be carried on without any disturbance.

Two of the three marble slabs which form the covering of the tomb were

a See also Scott's Gleanings from Westminster Abbey, p. 174. 
then examined, and it was ascertained that four iron studs had been inserted at the four corners to secure the parts of the old metal work which had disappeared. The corners of the marble have all been more or less strained by the force of the corrosion of these studs, the north-east corner was broken quite off and splintered, the other three were all cracked. There was also a wooden wedge found underneath the slab. It is evident that this belonged to the time when the slab was finally laid down in the reign of Henry V., and this fact, with the other indications just mentioned, is decisive that what is somewhat obscurely called by Mr. Amyot a the accidental opening of the tomb was only the peeping and thrusting in of the objects through the holes before mentioned in the side of the tomb.

It was not till the slab was lifted up that the actual nature of the tomb was disclosed.

The examination which followed, beginning on 3rd August, 1871, was carried on by the Dean, Canon Jennings, Sir Gilbert Scott, Mr. Doyne Bell, Mr. Richmond, Mr. George Scharf, Mr. Chance, Mr. C. Knight Watson, Mr. Sangster, Mr. John Scott, and Mr. C. S. Perceval.

The interior of the tomb consists of a chamber immediately under the marble slabs about $6 \frac{1}{2}$ feet deep, having the floor of the grave about 2 feet 6 inches below the floor of the Confessor's chapel, and about 1 foot 6 inches above that of the Ambulatory.

The lower part of the chamber is the grave, which is about 7 feet long and 5 feet wide, and over it is a space traversed longitudinally by an arch formed at about mid-height, so as to carry the two long slabs above, and dividing that space into two parts $8 \frac{1}{2}$ feet long and each about two feet wide.

The discovery that this low chamber was the actual vault is doubly interesting: It at once dispels the doubts which are expressed by Neale (vol. ii. p. 110), as to whether the bones seen in the last century through the apertures could really be the remains of the King and Queen; as it was more natural to suppose that they were interred in the upper portion of the tomb. It now seems that they were not, and this fact is also important, as indicating the transition from the custom followed in the earlier Plantagenet tombs to that adopted by the Tudors of interment in a separate vault.

On looking in, there were seen on the floor the broken and rotten boards of coffins, and bones, apparently in great disorder, especially two skulls which lay towards the foot of the grave. The Dean was at once summoned, and he directed

a Archrologia, vol. xx. p. 428, quoting Mr. King's account in Archæologia, vol. vi. p. 135. 
and superintended a closer examination. It was found that the contents had been subjected to much interference, and it was evident that they had been reached through the five holes formerly existing in the lower panelling of the south side, thus confirming the accounts given by historians of the Abbey, which state that these five holes, caused by the displacement of so many metal shields, were used hy visitors to pass in their hands, and thus the contents were felt and disturbed, and many portions abstracted and other objects introduced, as was soon proved."

On the 3rd of August, the Dean, Canon Jennings, Mr. Doyne Bell, and Mr. C. Knight Watson proceeded to examine the contents of the tomb.

The rotten elm boards of the coffins were first lifted out, and then the remains of the King and Queen were more visible; those of the King were lying chiefly on the north side, whilst those of the Queen remained on the south side as she had been placed by the King himself. These bones and the other contents of the grave were then all carefully handed out and examined by those present.

It was evident that several portions of the skeletons were missing, for instance, both the lower jaws ; ${ }^{b}$ and the crowns of copper said to have been seen through the holes on the south side were also not found. After all the bones that could be found had been removed, it was determined to sift the dust, and indeed the entire contents of the grave, so as to bring to light any minute objects which might otherwise escape observation. This was accordingly done, and the result was

a "From the side next the area," writes Dart (vol. ii. p. 45), "the arms are stolen, in the holes of which putting my hands, I could turn the boards of the coffin."

b The following is an extract from a letter recently received by the Dean.

"Wouldham Rectory, Rochester, " 30 June, 1873.

"It may be interesting to you to know that my grandfather Gerrard Andrewes, afterwards Dean of Canterbury, saw a Westminster scholar poke his hand into the tomb of Richard II. in the year 1766, and fish out the lower jaw-bone of the King. My grandfather received the jaw-bone from the boy, and it is now in my possession. I have often shown it to medical men, who say it is the jaw-bone of a man in the prime of life. There are two teeth remaining in the jaw. On a card attached to the bone is written (the handwriting is my grandfather's, Gerrard Andrewes), 'the jaw-bone of King Richard the Second taken out of his coffin by a Westminster scholar 1766.' My grandfather was himself a Westminster scholar at that time, sixteen years of age, having been born in $\mathbf{1 7 5 0}$.

$$
\text { “( Signed) }
$$

Charles Gerrard Andrewes."

A report by Mr. Sangster upon the human remains, together with letters upon the subject from Dr. Ugle and Professor Busk, will be found in Appendix (A). 
the production of several other objects, an entire list of which is given in Appendix (B). Mr. Doyne Bell made notes of all these proceedings.

Several articles found in the grave had undoubtedly been thrown in at various times through the holes already mentioned. But one remarkable object was found lying on the north side by the King's leg-bones and out of reach of the holes, namely : a large pair of plumber's shears, about $15 \frac{1}{2}$ inches long and 4 inches wide,

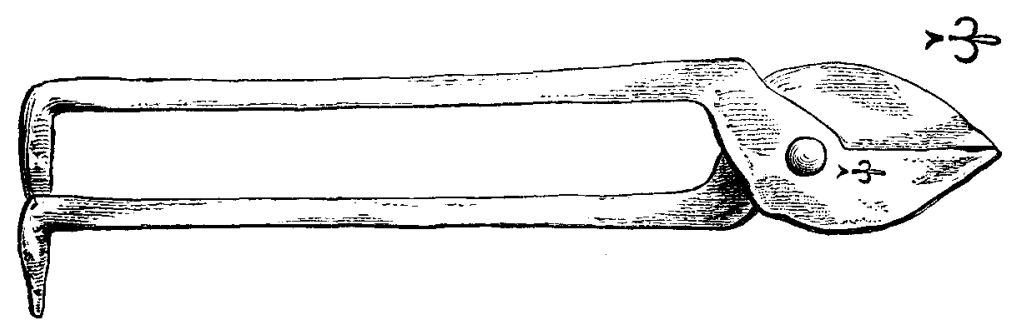

PLUMBER'S SHEARS OF IRON. LENGTH $15_{\frac{1}{2}}^{1}$ INCHES.

very nearly similar in form to those now in use. They are of great age, as shown by the amount of corrosion, and also by the trade stamp of a Plantagenet fleur-de.is; this is of elegant form, and stamped on the flat surface near the swivel. It is very likely that they were forgotten and left in the grave by the plumber who assisted at the interment in 1413. The leaden covering in which the body with the exception of the face was enveloped must have been removed, as only a very small piece of sheet lead was found in the grave. The leg-bones of the King, which were lying in correct position, and this pair of shears, had never been disturbed, and this is again an additional proof that the tomb had never been previously opened. ${ }^{a}$

The conclusions which are to be drawn from an examination of the skull of the King are not without interest. First, that it agrees with his well-known character, and with the general appearance of his portrait in the Abbey. This, however, supposing Maudelyn to have been exceedingly like him, proves nothing as to the identification of the bones as those of King Richard. Secondly, If these are the King's remains, then the story of the murder by Sir Piers Exton is, as has been long suspected, a mere legend. There is no mark of the battle-axe on the skull.

The iron cramps were all removed, and cramps of copper substituted for them,

a Mr. Doyne Bell has suggested that the leaden envelope might have been removed in order to enable the remains of the King either to be placed in the same wooden coffin or in immediate contiguity to the Queen ; in accordance with the same sentiment which prompted George II. to order the sides of his coffin and that of Queen Caroline to be removed. The boards which were thus removed were, in July, 1871, seen placed against the east wall in the Georgian vault in Henry the Seventh's Chapel.

VOL. XLV.

$2 \mathrm{~V}$ 
and, photographs having been taken of the skulls and the other bones, \&c., arrangements were made for closing the tomb. This was accordingly done on the 18th September, in the presence of the Dean, the Canons in residence, Mr. Doyne Bell, Mr. G. Scharf, and others. The bones of the King and Queen, being arranged as nearly as possible in their proper position, were inclosed in a chest with a division to separate them. On the lid of the chest the following words were inscribed, "The remains of Richard II. and his Queen." The objects which were believed to be connected with the original interments were placed in another chest and marked "Accompaniments of the interment of King Richard II. and his Queen." The articles which had evidently been intruded at a later period were likewise inclosed in a chest, and inscribed "Later insertions into the tomb of King Richard the Second."

Upon these three chests was laid a wooden tablet face downwards, in order that the inscription should remain clear as long as possible, inscribed as follows: "This tomb was opened during the repairs undertaken by the Office of Works in July 1871, and the contents of the tomb were then arranged by order of Arthur Penrhyn Stanley, D.D., Dean of Westminster."

Many portions of the bronze work belonging to this and other adjacent royal tombs are wanting, but no attempt at restoration has been made except by supplying cushions for the heads of Richard II. and his Queen, and of King Edward III. This was done at the suggestion of Her Majesty the Queen, who, upon the occasion of a visit to the Abbey, expressed regret at the neglectful and distressing appearance of these effigies being left without support to their heads. Careful models, adopted from contemporaneous forms, were prepared for these cushions, and these, after approval, were cast in bronze and water gilt; and they were also engraved with the diaper and heraldic devices of the King and Queen which are upon the effigies, table, and canopies, and which, now that the dirt of centuries has been removed, are again visible. These cushions have restored to the effigies that dignity and repose, the want of which had been so long lamented.

After the operations on the tomb had been completed, attention was directed to the wooden canopy above it, which being thickly incrusted with dirt and dust presented little hope of any improvement; although traces of the original paintings on the panels were discernible. One of the cross mouldings of the panels was missing, and the two adjacent pane]s were thereby much sunk and twisted. These defects were, however, remedied, and the sunken ceiling was corrected and strengthened. On the top boarding of the ceiling were observed very consider- 
able droppings of wax, from the wax lights which had formerly been placed above the tomb, and several of the boards were found to be much charred, as if they had been once on fire.

The paintings on the three panels are doubtless of the best art of the period. In the centre is a representation of the Coronation of the Virgin, with two graceful figures. The panels to the east and west have two angels on each of them, supporting shields of arms of the King and Queen. The outlines were still well defined, but the colours had much disappeared. The background of these paintings is on gesso and gilt, and most of this remains; the colouring on the mouldings and the gilt ornamentation is also in a fair state of preservation.

Mr. G. Richmond, R.A., kindly took in hand the restoration of these paintings as far as was possible, and with considerable success, as can be seen by all those who remember their former condition. ${ }^{\mathrm{a}}$ Towards the south side of the lower face of the tomb there are two splays which seem to have belonged to some erection antecedent to the present tomb of King Richard II. They are of firestone, and have a cavetto and bead moulding on the top, and something of the same character running northward, though both are carelessly placed. This recess may have contained a tomb which was removed to make place for that of the King: the concrete under the Queen's coffin and the portion of wall under the King's seem to indicate something of this nature. It may very probably have been the site of the beautiful early-English tomb of the two children of Humphrey de Bohun, now so awkwardly placed on the north side of the Chapel of St. John the Baptist.

\section{Tomb of Henry III.}

As there would have been considerable difficulty in cleansing the effigy and table-bed of the tomb of Henry III. in its place, it was decided to remove them into the Triforium, where the work could be carried on quietly and uninter-

a These paintings are described by Malcolm (Lond. Redivivum, 1802, vol. i. p. 96). He says, "One hundred years past it is probable that these pictures were tolerably perfect. If they had then been taken down and cleaned and preserved, and had last winter been put for Guido's, I am persuaded the deception would not have been discovered; now indeed the ravages of time have seized fast on them, and they will shortly owe their remembrance to works like mine." 
ruptedly. On the 24th October, 1871, they were therefore carefully displaced, and by means of powerful hoisting apparatus and strong scaffold work lifted up to the Triforium.

The effigy is in one entire piece, and the casting is of remarkable excellence, indeed it appears faultless. The thickness of the metal is considerable, measuring in some parts between 3 and 4 inches; it weighs about 12 cwt.

The metal table is of equal excellence, and, like the figure, is in one piece, and very truly cast. Its length is 7 feet 6 inches, and breadth 2 feet 9 inches, and its nearly uniform thickness is 1 inch; it weighs about 8 or 9 cwt. The united strength of nine men, with the help of pulley blocks, was required to raise the effigy and table, and they were successfully removed to the Triforium floor, there to undergo the process of cleansing.

The Purbeck marble bed on which the metal table is laid is in fair preservation; the exposed edges only have suffered some partial disintegration. There were no fastenings whatever to connect the effigy and its bed with the marble beneath, nor with each other; indeed the weight of each part was quite sufficient to make them immovable without the use of some special appliances, and there is no sign whatever in any of the parts to indicate that they had ever been displaced. Nothing was found under the effigy or metal table. They were so truly fitted to each other and to the marble, that there was hardly room for any insertion ; and everywhere round the edges the junction was rendered almost airtight by the indurated dust which had lodged there.

The marble bed consists of one long and two short pieces, making up a length of 7 feet 11 inches, and a width of 3 feet 2 inches, as shown in the woodcut. The long piece lies on the north side, and at its north-east corner there is a fracture

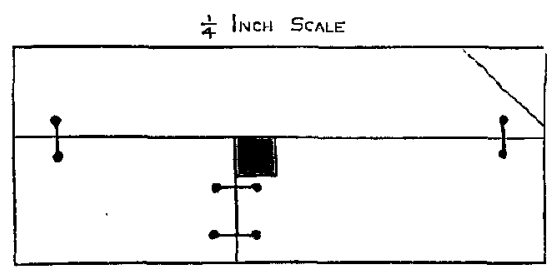

PLAN OF MARBLE BED. as shown, but the piece is only very slightly dislocated. There are four cramps, one of them loose and corroded at one end; the others are sound, and havg suffered but slightly from corrosion. The surface of the marble immediately under the metal is as perfect as it was at first, the small covering of dust which had insinuated itself, and was spread over it having tended to preserve it from the action of the air. At the junction of the three pieces of marble there is a neatly cut rectangular hole or notch. On looking through this hole into the space beneath, a flat surface about a foot below the marble bed was observed. This surface was at first thought to be a leaden box or coffin of perhaps a quarter of an inch in thickness. The smallness 
of the hole, and the distance to the lead, would not admit of the hand being inserted; from the same cause, the extent of the flat surface beneath could not be ascertained.

On Monday, the 6th of November, a strong light being thrown into this aperture of the tomb, and some of the black dust on the coffin being blown away, a tissue of cloth of gold was discevered in a condition of high preservation, and underneath it was perceived a sound and hard surface of wood, so compact that the touch and sound might easily be mistaken for those of lead, as was at first suggested.

On Tuesday, the 14th of Nordaber, the Dean having returned to London, directed the two small stones in question to be removed in his presence; Mr. Doyne C. Bell was also on the spot. The four cramps conjectured at first to be of iron were found to be only strips of lead run into cramp-shaped grooves, and the stones themselves were quite free to move. They had no intervening bed of mortar or plaster, but were so truly wrought and fitted together that no such bed was needed.

The two short stones being lifted on to the long one on the north side, the whole chamber or grave, with its coffin, became exposed, the latter nearly filling the space. It was now manifest that under a thin coating of black dust the coffin of wood was covered all over, top, sides, and ends, with cloth of gold, the warp of gold thread similar to that now used by our arras weavers; the weft being only of silk. It is woven in two alternating patterns of great beauty, consisting of striped stars and eight foils. (See woodcut.)

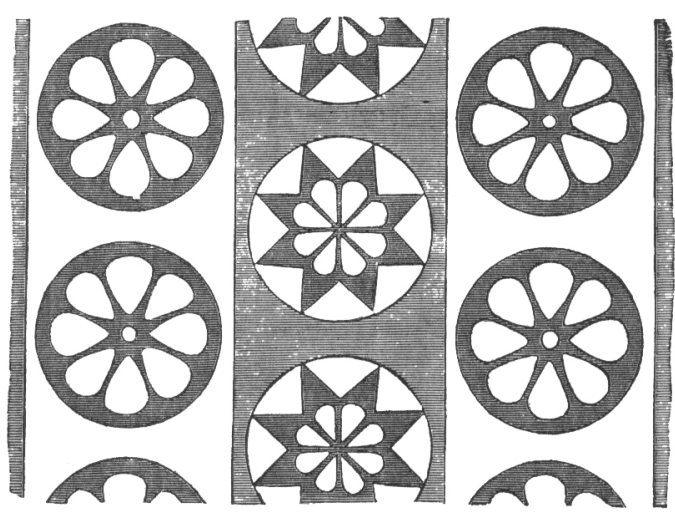

DIAPER OF THE CLOTH OF GOLD ON THE COFFIN OF HENRY III. SCALE $\frac{1}{2}$ LINEAR.

The cloth is in one continuous piece extending over the top, sides, and ends; the four corners not cut away but folded. This cloth, although at first sight in a good state, soon lost, from the action of the air, so much of the strength of its woof of silk and of the silken core within the gold twist that the force of wind from a small pair of hand bellows was sufficient to blow away both dust and silk. Yet, with the exception of a slight disturbance of that part immediately under the small hole in the slab, caused by the first endeavour to discover what was beneath, the whole surface was nearly intact. The colour of the silken fibre was far gone, but some portions of it retained a crimson hue. 
The wood of the lid, which is oak, is remarkably sound. Its upper surface is slightly decayed in some parts to the extent of about a quarter of an inch. The under surface appears to be quite sound, and this difference of the two surfaces

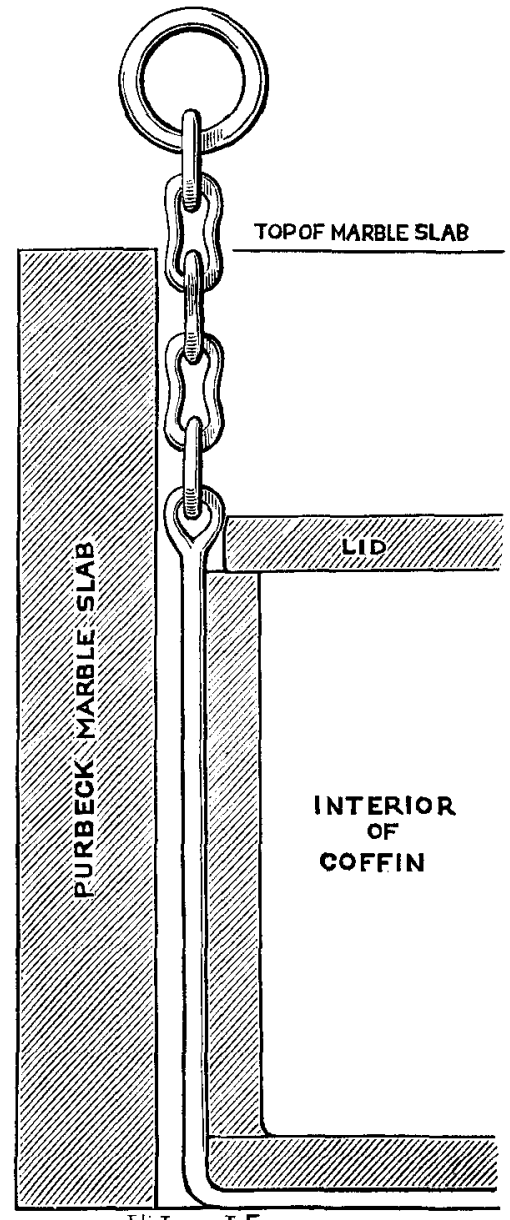

In IN:To I Foor

ARRANGEMENT OF CHAINS TO LET WOWN THE COFFIN. seems to have caused a warping upwards, so that there is an opening of an inch at the middle of the head, where the fingers may be inserted, and the lid was therefore found to be loose, and only held in position by its own weight.

The iron chains at the head, foot, and sides, whereby the coffin was carried and lowered into its chamber, yet remain. They are neatly made of wrought-iron bar, about half an inch in diameter. They terminate with rings 4 inches in diameter, large enough for the hands or for poles to be passed through them, so as to carry and lower the coffin. These rings and a few links of the chain were lying loose between the sides of the coffin and the marble tomb. The rings, when drawn out, rise a few inches above the edge of the tomb. These had been coated with a black resinous substance, which remained tolerably bright and smooth.

'The construction of the sides and ends of the chamber with the coffin inclosed is here shown; this latter measures 6 feet $1 \frac{1}{2}$ inch long, 1 foot $10 \frac{1}{2}$ inches wide at the head, and 1 foot 9 inches wide at the foot. Its top is at the head $21 \frac{1}{2}$ inches above the floor, and at the foot about 2 inches less. There is a recess of $4 \frac{1}{2}$ inches deep at the foot wrought in the block, made apparently to receive the foot of the coffin, but it is not wide enough, and therefore the forming of the recess has been of no practical use.

It will be seen on the plan on the next page that at each corner there are four iron cramps, and two long ones across to bind the tops of the side-slabs. All these cramps are corroded, but not extensively, as in most of the other Royal Tombs. There is no evaporation arising from below, owing to the impervious nature of the marble slab forming the floor of the chamber.

On the conclusion of this investigation, the Dean directed the marble covering 
to be replaced, and the tomb to be reopened on the following Thursday at four o'clock, requesting Mr. Doyne Bell to communicate with Mr. C. Knight Watson

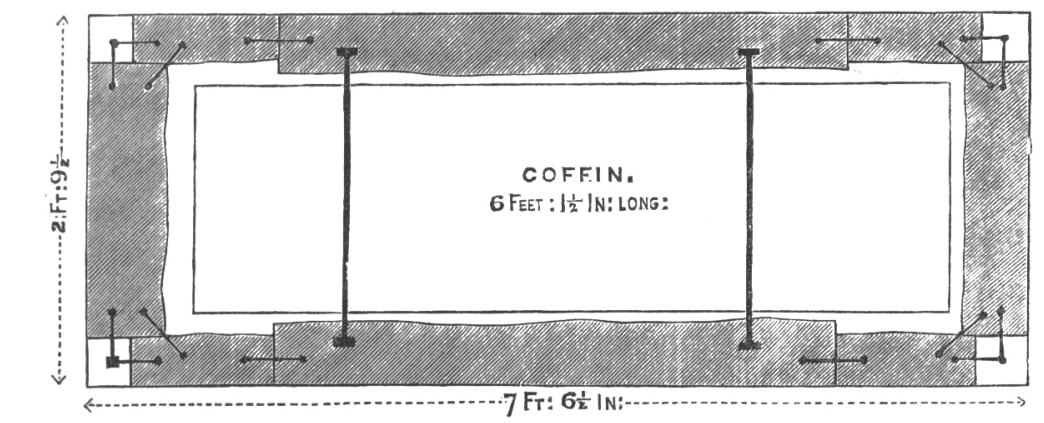

LONGITUDINAL SECTION OF TOMB SHOWING THE POSITION OF THE COFFIN, AND THE IRON STRAPS AND LOOPS FOR CHAINS.

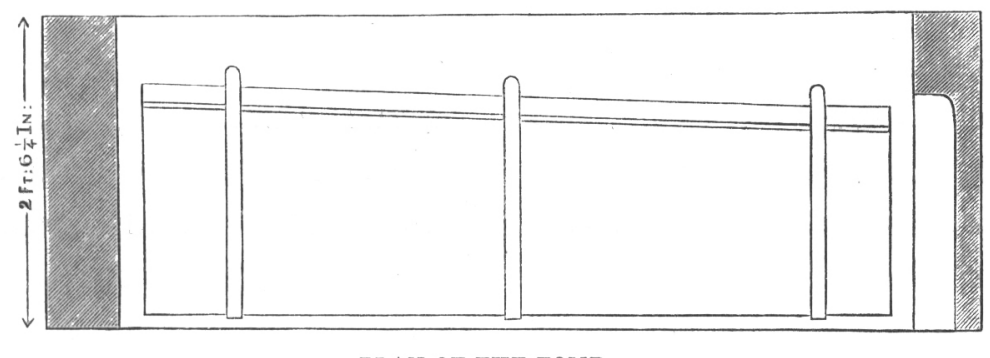

PLAN OF THE TOMB.

and Mr. Scharf, and directing Mr. Poole to inform Mr. Douglas Galton, of the Board of Works, so as to secure their attendance on the occasion.

On the 16th November there assembled the Dean, the Right Hon. A. S. Ayrton, First Commissioner of Works, Mr. Douglas Galton, Mr. C. Knight Watson, Mr. George Scharf, Mr. Doyne C. Bell, Mr. C. S. Perceval, Mr. Buckler, and Mr. Robertson. The two marble slabs covering the south side were again removed and accurate observations made of the structure, the cloth of gold, and the coffin; the dimensions of the various parts were recorded, and several notes and sketches were taken by Mr. G. Scharf. The separation of the cloth of gold at the head of the coffin-lid, caused, perhaps, partly by the warping there, enabled the cloth to be turned over at that point so that the surface of the wood beneath could be examined. It was then seen to be a beautiful slab of hard oak, smoothly wrought to almost a polish, thus showing that the apparent decay under the rectangular hole in the slab of marble was of but very limited extent.

After a most minute inspection of every part that could be thus seen, it was 
determined to reassemble on Monday the 28th inst., that the coffin-lid might be removed and the contents seen and carefully investigated; preparation was made for new copper cramps to be substituted for those of iron, and it was arranged that the final closing should take place immediately after the examination. The two slabs were then again replaced and the company dispersed.

The meeting took place on the 28th as arranged, and the slabs were again removed, when a feeling was found to prevail that there did not seem, upon historical grounds, to be sufficient motive to warrant the opening of the coffin. 'The project was therefore abandoned, the whole of the tomb finally closed in, and the effigy and bed replaced in their position over it. ${ }^{a}$

No fragment or insertion of any kind was found among any of the parts of the tomb that were removed or exposed, but during the cleansing of the bronze bed of the effigy an engraved outline was discovered in the metal; it is an unfinished group of three figures, composed of a robed and crowned female, ${ }^{b}$ standing in an attitude of devotion, and turned towards a figure of greater stature, also standing, but incomplete, showing only the robe and the right hand, while behind is a smaller female figure, also erect and devotional. The whole group is evidently the work of an accomplished artist. It may be some royal personage with an attendant in presence of a saint. It may be (although, perhaps, the crown is against the supposition) that the stately female figure represents the Abbess of Fontevraux receiving the heart of Henry III. on the occasion of his final re-interment, as described in the document discovered by Mr. Burtt in the archives of the abbey. A cast was made from the engraving, and placed in the Chapter House. (See Plate XXIII.)

a The only question which could arise was as to whether the King was buried in the sarcophagus of Edward the Confessor. It was evident that the wooden coffin in which he lies was made for him : the polish, the perfect state of the work, the ample folds of the pall, all proved this: and the Confessor's coffin was probably of stone.

b This figure is abont 10 inches high. 

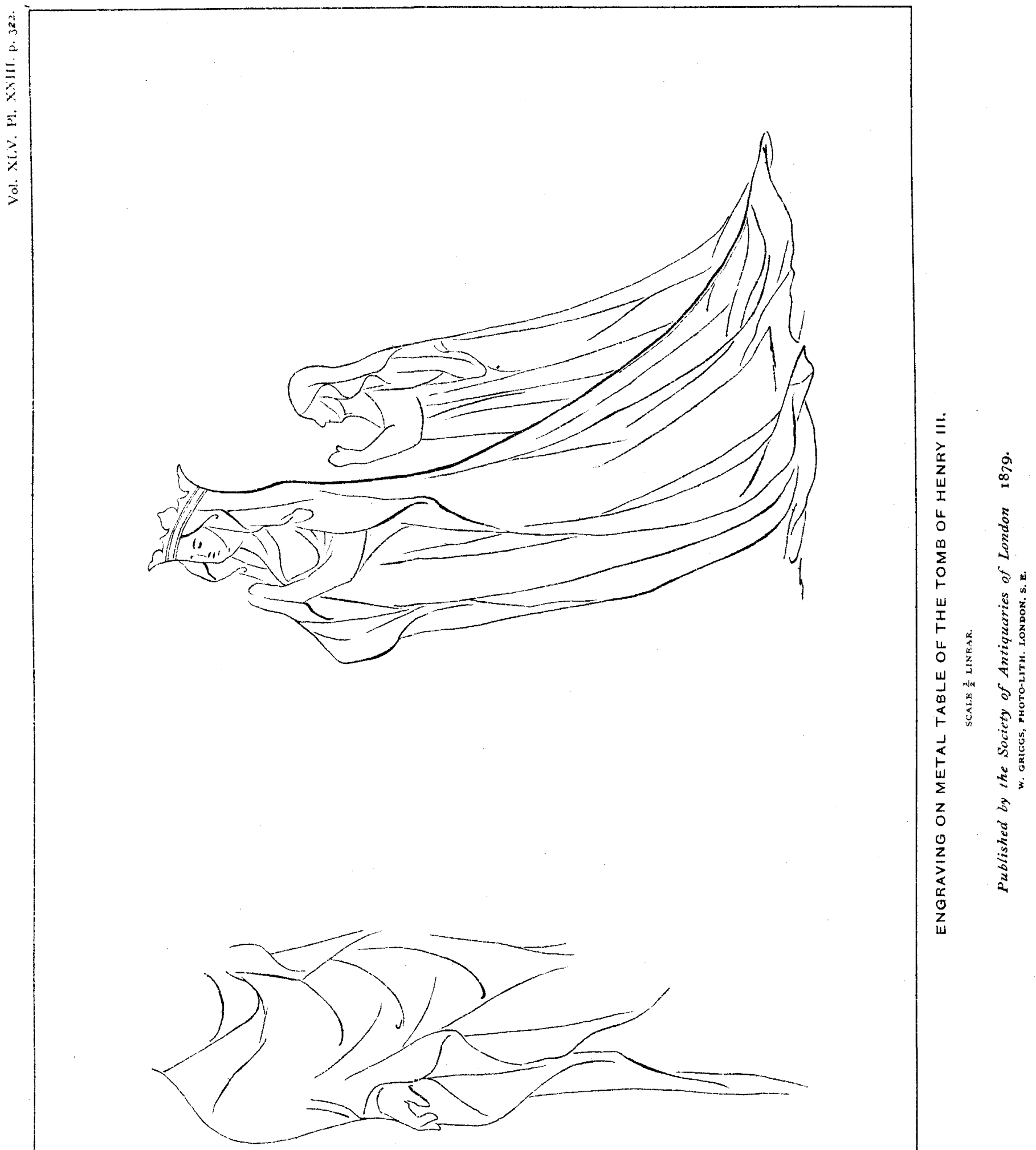


\section{APPENDIX (A).}

Mr. Sangster's Report upon the Human Bones found within the Tomb of Richard II. in Westminster ABBey.

The examination of the bones led to the conclusion that one skeleton belonged to a male and the other to a female.

Judging from the length and size altogether of the male bones, there can be no doubt that they belonged to a man nearly six feet in height.

The male skeleton was nearly perfect, the bones being all separate, very dry, and in a good state of preservation; the only ones which presented any decay were the right femur and the upper part of the sacrum.

Only the upper part of one scapula (right) was present, consisting of the head, two-thirds of the spine, together with the acromion and coracoid processes.

There were two upper pieces of the sternum. There was only one bone of the sacrum, which was much broken and decayed.

The following is a complete list of the male bones.

Skull

Right scapula and clavicle

, humerus

"radius

, ulna

, fos innominatum or

" Tilium, ischium and pubis

, femur yellower and more

, tibia $\{$ corroded than

" fibula the left

" patella

" astragalus and os calcis

The missing bones were the following:-

Left clavicle

, scapula

" patella

$\because$ os calcis

the lower jaw, some few vertebræ, ribs, small bones of the hands and feet and os coccygis.

The skull was large. The superciliary ridges were very small. The sutures were all perfect, and the only one which was gaping was the coronal (comnecting the frontal and parietal bones), the edges being sharp and well defined, showing that the bones had separated quite naturally.

VOL. XLV.

$2 \mathrm{x}$ 
The posterior part of the skull presented a very distorted appearance, and, instead of the occipital bone being convex externally, it was flat; and the lines (to which the strong muscles of the neck were attached), which usually curve outwards, were very prominent, and ran directly outwards. The base of the skull was perfect, excepting the styloid processes of the temporal bone, which had been broken off. The right mastoid process appeared to have been destroyed. In the upper jaw there was only the remains of one old stump; the teeth had fallen out by reason of the decay of the alveolar processes. Immediately under the left eye (in the superior maxilla or upper jaw), and continuous with the orbit, was a large circular piece of bone broken out.

The pelvis was perfect with the exception of the lower part of the sacrum. The remaining bones of the arms and legs were entire.

The bones which were recognised as belonging to the female skeleton were but few in number, belonged principally to the left side, and were very perfect.

They were the following:-

Skull, second cervical vertebra, two pieces of sternum and pelvis.

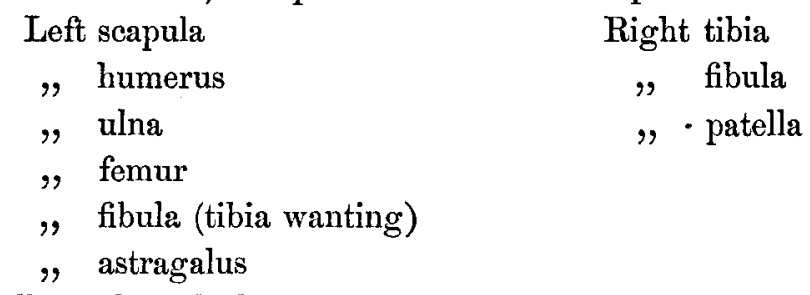

The skull was small; and, with the exception of the left temporal bone and styloid processes, was entire. The teeth were all missing. The lower jaw was wanting. The pelvis was large and well-formed, and measured from anterior superior spinous process on one side, to the same point on the other, 10 inches, from sacrum to pubis $5 \frac{3}{4}$ inches, and the transverse diameter was 5 inches.

Common to both: Twenty-nine ribs, beside fragments. Thirty-six vertebræ, more or less perfect, beside fragments. Metacarpal, metatarsal, and phalangeal bones, sixty-one in all. Seven tarsal bones.

There were ten teeth in good condition, five of which were double-fanged. One tooth was much decayed.

15, Lambeth Terrace, 2nd September, 1871.

Chas. Sangster, Surgeon.

\section{Memorandum by John W. Ogle, Esq., M.D., F.S.A.}

"There were two skulls, one much larger than the other, with a retiring forehead, very full and broad at the back of the head; the other, apparently that of a woman, having more forehead and much less preponderance behind. No lower jaw to either, and no teeth in the upper jaws. The large skull had the frontoparietal suture partially separate, and the other one had the left temporal bone almost quite wanting. No mark of injury otherwise on either. Bones of every part of the human body; also leg-bones, and a scapula of other animals. Curious, dark, very light- 
weighted mass, said to have come out of the skull ; this was reddish-brown, very friable, something of the shape and size of a patella, smooth and concave on its inner surface, very rough and fissured, and elevated on its outer surface. Query-Dried blood, or brain, or bone."

\section{Letter from Professor George BUSK, F.R.S.}

My DEAR Mr. Scharf,

32, Harley Street, 8th March, 1872.

I have measured the seed with which you filled the male skull found in the tomb of Richard II., and find that it occupies about eighty-nine cubic inches.

This capacity is below the average of English skulls, and very considerably under that of the more ancient inhabitants of Britain. The mean eapacity estimated from the data given by Thurnam and Davis in "Crania Britannica" of ancient Britons, as they term them, appears to be 96.3 cubic inches, of those in the Roman and Romano-British barrows 92.8 inches, and of the so-called Anglo-Saxons $\mathbf{9 1 \cdot 2}$ inches.

I am unable to refer to satisfactory data respecting more recent skulls, but I fancy the mean capacity for men in this country may be taken at from $90^{x}$ to 92 cubic inches. It would seem, therefore, that if this skull was filled as full as it would hold of the rape-seed, and that the seed has not shrunk since, King Richard the Second was not distinguished by the size of his brain. What its quality may have been is quite another question.

Yours very truly,

Geo. Busk. 


\section{APPENDIX (B).}

\section{List of ObJects found in the Tomb of King Richard II. in Westuinster Abbey.}

1. Plumber's shears with fleur-de-lis mark.

2. Wooden staff, query bow or part of a sceptre.

3. Brown leather riding gloves, one pair. The fingers of the right hand bent, those of the left quite straight. They are of flexible leather, without lining, gilding, or indication of the former attachment of precious stones. They are sewn with leather of the same colour, and appear by their creases to have been worn. (See woodcut.)

4. A smaller pair of leather gloves, much more rotten, about seven inches long.

5. Double rose in lead, the same pattern on both sides.

6. Four small fragments of green porphyry slab, smooth, flat surface.

7. Small fragments of wood, like twigs. ${ }^{a}$ One piece of very light yellow colour, shaped like a reel, having black lines round it.

8. Pieces of linen, leather of shoes, binding, and plugget of tow.

9. Four pieces of shaped cork.

10. A handful of toy marbles.

11. Three tobacco-pipe bowls, one with stem five inches long.

12. Seventy-two copper coins and tokens.

13. Alabaster carved flower, with green centre, outer leaves gilt, a fragment.

14. Two segments of a common leather ball, measuring $2 \frac{5}{8}$ inches from apex to apex.

15. Gilt wooden finial, perhaps part of a sceptre.

16. Fragments of window-glass, plain and wrought.

17. Decayed pieces of Purbeck marble.

18. Small square piece of cedar-wood.

19. Iron buckle.

20. A Jew's harp.

21. Leaden round buttons, dog's bell for collar.

22. One flat button of copper gilt, with basket pattern on it.

23. Bird's bones.

24. Two long pieces of corroded steel, query weapons, one of them was 1 foot $\frac{1}{2}$ inch long.

25. Ten human teeth found in sifting the dust, in good condition, five of them double-pronged.

a The bark upon these was perfect when they were first found, but they almost all crumbled to dust when tonched. These had donbtless been placed there as a precaution against witcheraft. Similar twigs were found on opening Henry IV.'s tomb at Canterbury Cathedral. See "A brief account of the exanination of the tomb of Henry IV. 21 Aug. 1832," by J. H. S. [Dr. Spry, then canon of Canterbury.] 
26. Three broken knives with handles, one of them a small table-knife.

27. Iron nails of the coffins.

28. A paving-tile, painted with a shield bearing three lions.

29. Seven silver coins (a harp on one).

30. Fragment of wood, possibly of a sceptre.

31. Small fragment of a stone cusp or spandril.

32. Fragments of red glazed pottery, like of a pipkin.

33. A small piece of corroded sheet-lead.

34. One iron square-pointed nail, seven inches long.

35. Nine fragments of iron nails, seven with heads, and the longest measuring $2 \frac{3}{4}$ inches, were found among the human bones.

36. A peach-stone. Splinters of wood.

37. Bottle-stamp, Dr. Blair, 1763. [Dr. John Blair, prebendary of Westminster, 1761-1782.]

38. Two cut pieces of glass and crystal, apparently from a ring.

39. Small lump of uncertain matter formed like a patella.

40. Some fragments of the silk pall with a spotted pattern.
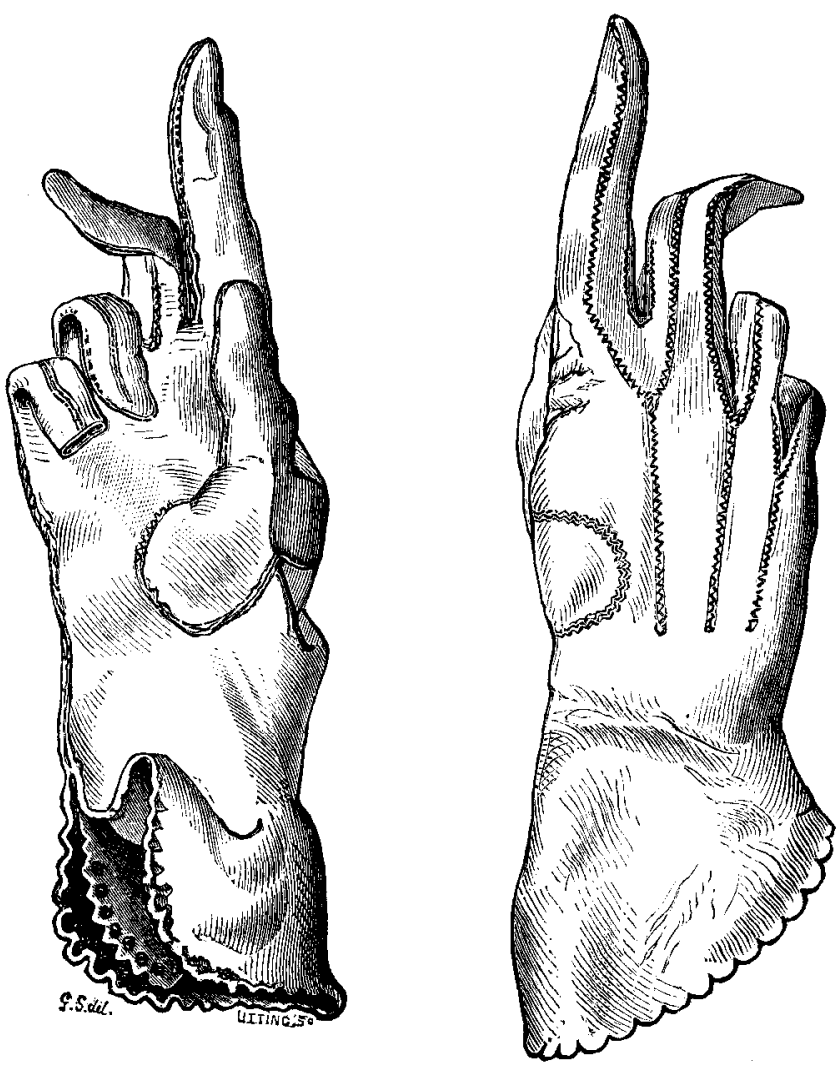

ONE OF THE LEATHER RIDING GLOVES FOUND IN THE TOMB OF RICHARD 11. LENGTH $8 \frac{8}{8}$ IN. 